\title{
Haemodynamic studies on newly diagnosed diabetics before and after adequate insulin treatment
}

\author{
S. Carlström and T. Karlefors ${ }^{1}$ \\ From the Department of Internal Medicine and Clinical Physiology, University Hospital, \\ Lund, Sweden
}

Haemodynamic observations were made during a short period of physical exercise on 10 male juvenile diabetics as soon as the diagnosis was made and again after adequate insulin treatment. It was found that the intra-arterial pressures rose to higher levels than in the control subjects at both examinations. The stroke volume increased and the heart rate decreased between the two examinations. These changes are tentatively attributed to metabolic adjustments after insulin therapy, offering more favourable conditions for the work of the heart muscle.

Haemodynamic studies at rest and during exercise were carried out by Karlefors (I966) on men with diabetes of different duration and severity. He reported that the diabetics had a lower cardiac output during exercise due to a decreased stroke volume, in comparison with control subjects. At rest, no difference was noticed. Karlefors also reported raised intra-arterial pressures during exercise in the diabetic groups.

The aim of the present study was to find out if this decreased stroke volume during exercise occurs in recently recognized diabetics. For this reason, men with recently diagnosed juvenile diabetes were examined haemodynamically at rest and during moderate physical exercise before starting insulin therapy. Later on, when the disease had been controlled with adequate insulin therapy, the examination was repeated. In preliminary communications we have reported that the intra-arterial pressures during exercise rose to higher levels in newly diagnosed, male juvenile diabetics than in control subjects of the same age (Carlström and Karlefors, 1967a), and that this exercise-induced hypertension was not modified by adequate insulin treatment for about 6 months (Carlström and Karlefors, 1967b).

\section{Material and methods}

Ten male subjects in whom juvenile diabetes had recently been diagnosed were selected for the present study. They were examined twice; before

Received 2 July 1969.

1 Deceased. and after approximately one year's adequate insulin treatment. The diagnosis of diabetes was based either upon fasting blood sugar above 150 $\mathrm{mg}$./ $100 \mathrm{ml}$. or on a diabetic oral glucose tolerance test using the criteria of Schersten (1966). All the patients had subjective symptoms of diabetes including increased thirst, polyuria, and, in some cases, loss of weight. Some clinical data of the patients examined are summarized in Table $\mathrm{r}$. Cases 2, 4, 5, and 6 were examined after an overnight fast at both examinations and did not get their ordinary insulin dosage before the second examination. The other patients were examined on both occasions about one hour after a breakfast of tea and bread and butter. These patients got their ordinary morning insulin dose at the second examination.

The examination started with the insertion of polythene catheters under local anaesthesia (mepivacaine, I\% solution). One catheter was placed in the brachial artery and another in one of the cubital veins and advanced to the subclavian vein. When samples were not taken, the catheters were filled with physiological saline and in some of the patients (Cases 2, 4, 5, 6) a small amount of heparin ( $50 \mathrm{mg}$. to $500 \mathrm{ml}$.) was added.

After insertion of the catheters the patients were allowed to rest for about $1 \frac{1}{2}$ hours. The patients then performed physical work on a bicycle ergometer in the supine position. The work load was $600 \mathrm{kpm}$. per minute.

The heart rate was registered on the electrocardiogram. The intra-arterial pressures were determined by an inductance manometer and the mean pressures obtained by electrical integration. ${ }^{1}$ The cardiac output was measured with the indicator dilution technique using bromsulphalein as the indicator (Wassén, 1956). Expired air

\footnotetext{
${ }^{1}$ Equipment was Elema, Sweden.
} 
was collected in Douglas bags and analysed for $\mathrm{O}_{2}$ and $\mathrm{CO}_{2}$ by the Scholander technique (Scholander, 1947). Base excess, $\mathrm{PCO}_{2}$, and $\mathrm{pH}$ in arterial blood were measured by the Astrup micro-technique, as described by Siggaard Andersen (1962). Oxygen saturation in arterial blood was determined spectrometrically (Holmgren and Pernow, 1959). Blood sugar was estimated according to Marks with a glucose oxidase method (Marks, I959). The statistical evaluation was made with Wilcoxon's rank sum test (Wilcoxon, 1945).

The haemodynamic measurements were made during the resting period before the exercise and were repeated between the sixth and eighth minutes of exercise when the patients were in a steady circulatory state. Steady state was considered to be present when the heart rate did not increase by more than four beats in two minutes. Blood sugar was measured at intervals during the entire examination, and the other chemical determinations immediately before and after about seven minutes of exercise.

\section{Results}

The results of the measurements are summarized in Table 2. It is apparent from the Table that the diabetics had gained in weight between the first and the second examination. This difference is, however, not significant. It is reasonable to assume that the diabetics had lost weight before the discovery of the diabetes and that this weight loss was compensated for during treatment. There are no differences between the resting data at the two examinations except for the blood sugar. None of the diabetics was dehydrated or in a state of ketoacidosis at any of the examinations. The blood sugar level during the examination, which is the mean of 17 determinations in each subject, showed no significant fluctuations, but the mean level of the whole group was, as expected, higher at the first examination.

During exercise, the intra-arterial pressures rose to about the same level at both examinations. In Fig. I the mean intra-arterial pressures during exercise are graphically represented, and for comparison the mean intra-arterial pressures during exercise in a group of control subjects of the same age, examined earlier, are given (Carlström and Karlefors, 1967a). It is clear that the diabetic group on both occasions reached higher intra-arterial pressures than the control group, and that there were no differences between the data of the two examinations of the diabetic group.

In Fig. 2 other haemodynamic measurements of the diabetics at the two examinations are presented graphically together with data from a group of control subjects of the
TABLE I Details of the patients at the first examination

\begin{tabular}{|c|c|c|c|c|c|c|}
\hline $\begin{array}{l}\text { Case } \\
\text { No. }\end{array}$ & $\begin{array}{l}\text { Age } \\
(y r .)\end{array}$ & $\begin{array}{l}\text { Height| } \\
\text { weight } \\
\text { (cm./kg.) }\end{array}$ & $\begin{array}{l}\text { Plasma } \\
\text { creatinine } \\
\text { (mg./roo ml.) }\end{array}$ & $\begin{array}{l}\text { Blood } \\
\text { pressure } \\
(\mathrm{mm} . \mathrm{Hg})\end{array}$ & $\begin{array}{l}\text { Duration } \\
\text { of symp- } \\
\text { toms (wk.) }\end{array}$ & $\begin{array}{l}\text { Complica- } \\
\text { tions }\end{array}$ \\
\hline I & 32 & $181 / 75 \cdot 7$ & 0.7 & $140 / 90$ & 3 & 0 \\
\hline 2 & 21 & $172 / 62 \cdot 0$ & 0.9 & $140 / 80$ & 6 & 0 \\
\hline 3 & $2 I$ & $174 / 57.5$ & (NPN 36) & $140 / 85$ & 4 & 0 \\
\hline 4 & 23 & $179 / 64 \cdot 5$ & $\mathrm{I} \cdot \mathrm{O}$ & $140 / 90$ & 8 & 0 \\
\hline 5 & 17 & $171 / 56.7$ & 0.8 & $135 / 80$ & 2 & 0 \\
\hline 6 & 25 & $18 \mathrm{I} / 7 \mathrm{I} \cdot 3$ & (NPN 30) & $140 / 80$ & 8 & 0 \\
\hline 7 & 19 & $179 / 63.0$ & I. IO & $145 / 75$ & 3 & 0 \\
\hline 8 & 19 & $185 / 71 \cdot 7$ & $I \cdot 10$ & $125 / 90$ & 4 & 0 \\
\hline 9 & 22 & $173 / 58.5$ & $(\mathrm{NPN} 36)$ & $140 / 80$ & 4 & 0 \\
\hline 10 & 28 & $182 / 75^{\circ} 6$ & $(\mathrm{NPN} 30)$ & $145 / 90$ & 9 & 0 \\
\hline
\end{tabular}

$\mathrm{NPN}=$ non-protein nitrogen

TABLE 2 Some data on diabetic subjects

before and after insulin treatment at rest

and during exercise (work load, $600 \mathrm{kpm} . / \mathrm{min}$.)

\begin{tabular}{|c|c|c|c|c|c|c|c|c|}
\hline & & \multicolumn{2}{|c|}{ Before insulin } & \multirow[b]{2}{*}{ No. } & \multicolumn{2}{|c|}{ After insulin } & \multirow{2}{*}{ No. } & \multirow{2}{*}{$\begin{array}{l}\text { Significance } \\
\text { level }\end{array}$} \\
\hline & & Mean & $S E M$ & & Mean & $S E M$ & & \\
\hline \multirow{2}{*}{\multicolumn{2}{|c|}{$\begin{array}{l}\text { Age (yr.) } \\
\text { Height (cm.) }\end{array}$}} & $22 \cdot 7$ & $I \cdot 44$ & ro & 23.9 & $\mathrm{I} \cdot 54$ & 10 & NS \\
\hline & & $177 \cdot 7$ & $1 \cdot 53$ & I0 & 178.6 & $1 \cdot 38$ & I0 & NS \\
\hline \multicolumn{2}{|c|}{ Weight (kg.) } & $65 \cdot 7$ & $2 \cdot 33$ & IO & $70 \cdot 7$ & $2 \cdot 57$ & I0 & NS \\
\hline \multirow{2}{*}{$\begin{array}{l}\text { Heart rate } \\
\text { (beats/ } \\
\text { min.) }\end{array}$} & Rest & $67 \cdot 7$ & $4 \cdot 22$ & IO & $67 \cdot 5$ & $3 \cdot 77$ & I0 & NS \\
\hline & Exercise & $149 \cdot 4$ & $5 \cdot 94$ & I0 & $130 \cdot 2$ & 3.63 & ro & $\mathrm{p}<0.05$ \\
\hline \multirow{2}{*}{$\begin{array}{l}\text { Cardiac out- } \\
\text { put } \\
\text { (1./min.) }\end{array}$} & Rest & $7 \cdot 48$ & 0.49 & I0 & $7 \cdot 58$ & 0.65 & IO & NS \\
\hline & Exercise & $16 \cdot 30$ & $I \cdot O I$ & I0 & $16 \cdot 73$ & 0.66 & IO & NS \\
\hline $\begin{array}{l}\text { Stroke vol- } \\
\text { ume (ml.) }\end{array}$ & Rest & I I I 4 & $5 \cdot 34$ & I0 & I I I '9 & $6 \cdot 52$ & I0 & NS \\
\hline \multicolumn{9}{|c|}{$\begin{array}{l}\text { Brach. art. } \\
\text { pressure } \\
(\mathrm{mm} . \mathrm{Hg})\end{array}$} \\
\hline \multirow[t]{2}{*}{ Syst. } & Rest & $127 \cdot 6$ & $5 \cdot 75$ & I0 & $127 \cdot 1$ & $3 \cdot 74$ & I0 & NS \\
\hline & Exercise & $176 \cdot 4$ & $6 \cdot 29$ & I0 & 176.4 & $7 \cdot 34$ & I0 & NS \\
\hline \multirow[t]{2}{*}{ Diast. } & Rest & $70 \cdot 7$ & I.89 & 10 & $71 \cdot 2$ & $2 \cdot 33$ & 10 & NS \\
\hline & Exercise & $88 \cdot 1$ & $2 \cdot 88$ & 10 & $\begin{array}{l}83 \cdot 1 \\
92 \cdot 4\end{array}$ & $\begin{array}{l}4.01 \\
2 \cdot 78\end{array}$ & 10. & $\begin{array}{l}\text { NS } \\
\text { NS }\end{array}$ \\
\hline Mean & Rest & $90 \cdot 8$ & $3 \cdot 11$ & 10 & $\begin{array}{r}92.4 \\
116.9\end{array}$ & $\begin{array}{l}2 \cdot 78 \\
4 \cdot 77\end{array}$ & 10 & $\begin{array}{l}\text { NS } \\
\text { NS }\end{array}$ \\
\hline \multirow{2}{*}{$\begin{array}{l}\text { Calculated } \\
\text { vascular } \\
\text { resistance }\end{array}$} & $\begin{array}{l}\text { Exercise } \\
\text { Rest }\end{array}$ & $\begin{array}{r}115.1 \\
12.6\end{array}$ & $\begin{array}{l}2.42 \\
0.92\end{array}$ & $\begin{array}{l}\text { I0 } \\
\text { 10 }\end{array}$ & $\begin{array}{r}116.9 \\
12.9\end{array}$ & $\begin{array}{l}4.77 \\
0.95\end{array}$ & $\begin{array}{l}10 \\
10\end{array}$ & $\begin{array}{l}\text { NS } \\
\text { NS }\end{array}$ \\
\hline & Exercise & $\begin{array}{c}12 \cdot 0 \\
7 \cdot 27\end{array}$ & $\begin{array}{l}0.92 \\
0.46\end{array}$ & $\begin{array}{l}\text { 10 } \\
\text { I0 }\end{array}$ & $\begin{array}{c}12.9 \\
7.05\end{array}$ & $\begin{array}{l}0.95 \\
0.35\end{array}$ & $\begin{array}{l}10 \\
10\end{array}$ & NS \\
\hline \multirow{2}{*}{$\begin{array}{l}\text { Oxygen } \\
\text { uptake } \\
\text { (ml./min.) }\end{array}$} & Rest & $302 \cdot 7$ & $17 \cdot 1$ & 10 & $301 \cdot 9$ & $15 \cdot 24$ & I0 & NS \\
\hline & Exercise & 1599.6 & $43 \cdot 7$ & I0 & 1504.8 & $44 \cdot 5$ & IO & NS \\
\hline \multirow[t]{2}{*}{ RQ } & Rest & 0.77 & 0.02 & I0 & 0.75 & 0.01 & I0 & NS \\
\hline & Exercise & 0.85 & 0.02 & ro & 0.87 & 0.03 & 10 & NS \\
\hline \multirow[t]{2}{*}{$p H$} & Rest & $7 \cdot 412$ & 0.011 & 10 & $7 \cdot 403$ & 0.010 & ro & NS \\
\hline & Exercise & $7 \cdot 375$ & 0.008 & 10 & $7 \cdot 364$ & 0.010 & I0 & NS \\
\hline \multirow{2}{*}{$\begin{array}{l}\text { Base excess } \\
(\mathrm{mEq} / \mathrm{l} .)\end{array}$} & Rest & -0.06 & 0.489 & 9 & -0.80 & 0.410 & 10 & NS \\
\hline & Exercise & $-2 \cdot 15$ & 0.619 & ro & -3.05 & 0.353 & IO & NS \\
\hline \multirow{2}{*}{ Haematocrit } & Rest & $43 \cdot 3$ & $I \cdot 3 I$ & IO & $42 \cdot 9$ & $I \cdot O I$ & IO & NS \\
\hline & Exercise & $44 \cdot 6$ & I 25 & I0 & $45 \cdot 4$ & $0.8 I$ & I0 & NS \\
\hline \multicolumn{2}{|c|}{$\begin{array}{l}\text { Blood glucose } \\
\text { (mg./ } \\
\text { roo ml.) }\end{array}$} & $198 \cdot 4$ & $17 \cdot 7$ & I0 & I I I $\cdot 2$ & $13 \cdot 0$ & 10 & $p<0.001$ \\
\hline
\end{tabular}

NS = not significant. SEM $=$ standard error. 


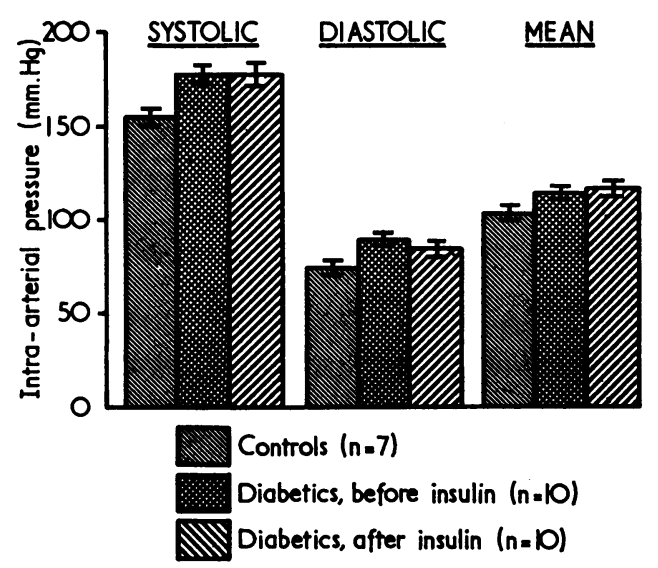

FIG. I The systolic, diastolic, and mean intra-arterial pressures during exercise in a group of control subjects and diabetics before and after insulin treatment.

same age, previously published (Carlström and Karlefors, I967a). The mean heart rate shows a tendency to be higher and the mean stroke volume to be lower in the diabetic group at the first examination in comparison with the control group, but neither of these differences is statistically significant. At the second examination the diabetic patients showed a mean stroke volume significantly ( $p<0.05$ ) higher than that of the first examination, but as the mean heart rate decreased, the mean cardiac output remained unchanged.

The difference in stroke volume was seen only during exercise, the values at rest being the same before and after treatment. Inability to increase in stroke volume can thus be said to be the essential difference between non-treated and treated diabetics.

\section{Discussion}

In diabetics, the blood pressure rises to higher levels during exercise than in comparable control subjects (Karlefors, 1966). This abnormal reaction to exercise seems to be already present at the onset of the disease and is not modified by adequate insulin therapy for about one year. These findings may support the theory that there are structural changes in the arterial wall early in diabetes (British Medical fournal, I965), but they are reflected in the blood pressure figures only when the cardiac output is increased. At rest no increase in intra-arterial pressures was noticed.

As found by Karlefors (I966), the stroke volume of the diabetics during exercise was decreased in comparison with that of control subjects. In the present investigation the car-
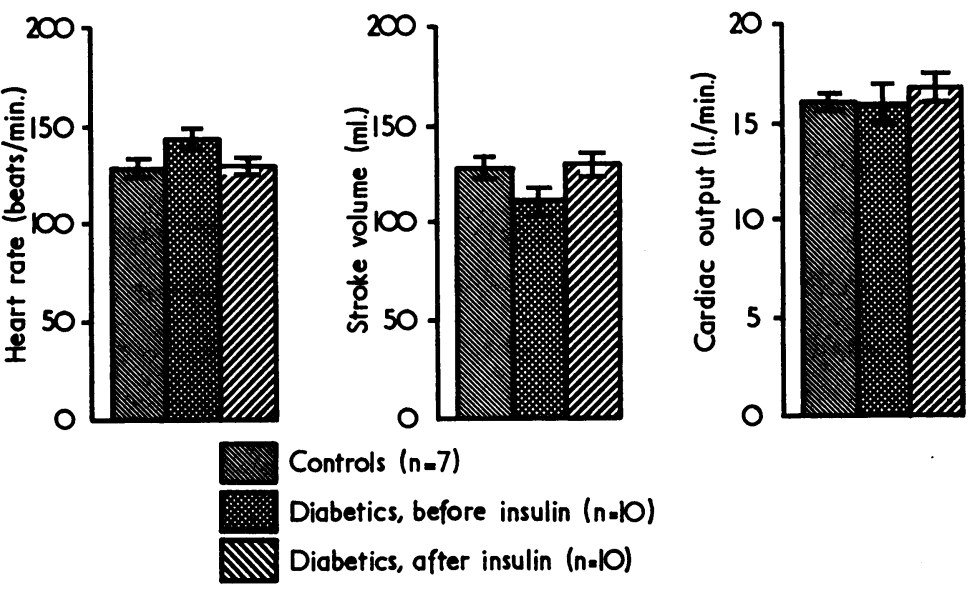

FIG. 2 The heart rate, stroke volume, and cardiac output during exercise in a group of control subjects and diabetics before and after insulin treatment.

diac output was not lowered because of a higher heart rate. This finding may seem to contradict that of Karlefors (I966) but the two studies are not comparable.

The possibility that the increase in stroke volume during exercise and decrease in heart rate between the two examinations might be explained by an improvement in the general condition of the patients, can be discounted because all had been at work when the diagnosis was made, none of them was dehydrated or ketoacidotic, or had any symptoms apart from those of early diabetes. Normally our diabetic patients are recommended to take exercise, but this was not done here, and none of them had trained physically or changed occupation between the two examinations. It is unlikely therefore that the higher stroke volume and lower heart rate at the second examinations are the results of training.

Carlsten and his colleagues studied the myocardial arteriovenous difference of several metabolites in diabetics before and after insulin (Carlsten et al., I966). They showed that insulin lowered the myocardial free fatty acid extraction in the diabetics to about the level found in control subjects. They found no difference in the myocardial extraction of glucose before and after insulin which was similar to control values. The authors suggested that the diabetic heart muscle after insulin administration increased the oxidation of other substances such as ketone bodies, plasma triglycerides, or substrates stored in the heart muscle, and consequently decreased the oxidation of free fatty acids. 
Apparently insulin treatment in diabetics can adjust myocardial metabolism towards normal. This may explain the increased stroke volume in our patients at the second examination.

The fact that the resting stroke volume was normal but did not increase during exercise suggests that any deranged metabolism exerts its influence only when the work of the heart is increased.

The technical assistance of Nurses Elin Höglund and Anita Månsson, and Miss Anita Jönsson is gratefully acknowledged.

The study was supported by grants from the Medical Faculty, University of Lund, Lund, Sweden, 'Svenska Diabetesförbundet', Stockholm, Sweden, and 'Nordisk Insulinfond', Copenhagen, Denmark.

\section{References}

British Medical fournal (1965). Editorial. Vascular lesions of diabetes mellitus. 2, 603 .

Carlsten, A., Hallgren, B., Jagenburg, R., Svanborg, A., and Werkö, L. (1966). Amino acids and free fatty acids in plasma in diabetes. II. The myocardial arterio-venous differences before and after insulin. Acta Medica Scandinavica, 179, 631.

Carlström, S., and Karlefors, T. (1967a). Haemodynamic studies during exercise in newly diagnosed juvenile diabetics. Acta Medica Scandinavica, 181, 759.
, and - (1967b). Studies on fatty acid metabolism in diabetics during exercise, IV. Plasma free fatty acid concentrations and hemodynamics in juvenile diabetics during exercise before and after insulin treatment. Acta Medica Scandinavica, 181, 747.

Holmgren, A., and Pernow, B. (1959). Spectrophotometric measurement of oxygen saturation of blood in the determination of cardiac output. A comparison with the van Slyke method. Scandinavian fournal of Clinical and Laboratory Investigation, 11, 143.

Karlefors, T. (1966). Haemodynamic studies in male diabetics. Acta Medica Scandinavica, Suppl. 449.

Marks, V. (1959). An improved glucose-oxidase method for determining blood, C.S.F. and urine glucose levels. Clinica Chimica Acta, 4, 395.

Scherstén, B. (1966). Health control. VI. Evaluation of screening methods for diabetes. (Swedish.) Läkartidningen, 63, 2659.

Scholander, P. F. (1947). Analyzer for accurate estimation of respiratory gases in one-half cubic centimetre samples. Fournal of Biological Chemistry, 167, 235.

Siggaard Andersen, O. (1962). The pH-log $\mathrm{pCO}_{2}$ blood acid-base nomogram revised. Scandinavian fournal of Clinical and Laboratory Investigation, 14, 598.

Wassén, A. (1956). The use of bromsulfphalein for determination of the cardiac output. Scandinavian fournal of Clinical and Laboratory Investigation, 8, 189.

Wilcoxon, F. (1945). Individual comparisons by ranking methods. Biometrics, $\mathbf{1}, 80$. 